\title{
Neuroprotective effects of herbal mixture HT070 on global cerebral ischemia in rats
}

\author{
Jungbin Song ${ }^{1 \#}$, Donghun Lee ${ }^{1}$, Young-Sik Kim² ${ }^{2}$,Hyun Jeong Lee ${ }^{2}$, Seunggyeong Lee ${ }^{2}$, \\ Dong Kuk Kim ${ }^{3}$, Shin Ho Kang ${ }^{3}$, Yong Kook Shin ${ }^{3}$, Ho-Young $\mathrm{Choi}^{1}$, Hocheol Kim ${ }^{1^{*}}$ \\ 1 : Dept. of Herbal Pharmacology, College of Korean Medicine, Kyung Hee University \\ 2 : Dept. of Science in Korean Medicine, Graduate School, Kyung Hee University \\ 3 : R\&D Center, Seoul Dairy Cooperative
}

\begin{abstract}
Objectives : HT070 is a mixture of herbal extracts from root of Scutellaria baicalensis and stem bark of Eleutherococcus senticosus, which have long been used for stroke therapy in traditional Korean Medicine. The purpose of this study was to investigate the neuroprotective effects of HT070 on global cerebral ischemia and its potential mechanisms.

Methods : Transient global cerebral ischemia was produced by 10 min of four-vessel occlusion (4-VO) in male Wistar rats. HT070 was administered orally at a dosage of $200 \mathrm{mg} / \mathrm{kg}$ twice at 0 and $90 \mathrm{~min}$ after reperfusion. Hippocampal neuronal damage was measured 7 days after reperfusion. To explore the potential mechanisms, we used hydrogen peroxide $\left(\mathrm{H}_{2} \mathrm{O}_{2}\right)$-induced rat pheochromocytoma (PC12) cells as an in vitro model. PC12 cells were pretreated with $\mathrm{HT070}$ for $1 \mathrm{~h}$ and then exposed to $100 \mu \mathrm{M} \mathrm{H}_{2} \mathrm{O}_{2}$ for $6 \mathrm{~h}$ in the presence of HT070. Cell viability was measured by MTT assay and the mRNA expression of Bax, Bcl-2, iNOS and COX-2 were measured by quantitative RT-PCR.

Results : Oral administration of $\mathrm{HTO} 70$ at a dose of $200 \mathrm{mg} / \mathrm{kg}$ significantly reduced neuronal death in the hippocampal CA1 region by $13.4 \%$ as compared to the vehicle-treated group. HT070 increased cell viability, reversed the down-regulated Bcl-2 mRNA level, and suppressed the up-regulated mRNA expressions of Bax, iNOS, and $\mathrm{COX}-2$ in $\mathrm{H}_{2} \mathrm{O}_{2}$-treated $\mathrm{PC} 12$ cells.

Conclusions : HT070 protects against delayed neuronal death after global cerebral ischemia and its neuroprotection properties might be attributed to the inhibition of mitochondrial apoptosis and ROS-generating enzymes.
\end{abstract}

Key words : HT070, Scutellaria baicalensis, Eleutherococcus senticosus, global cerebral ischemia, four-vessel occlusion, neuroprotection, oxidative stress, hydrogen peroxide

\section{I . Introduction}

Global cerebral ischemia generally occurs during cardiac arrest or severe systemic hypotension that hinders the supply of oxygen and glucose to the brain for short periods of time. It causes a slow development of cell death in brain neurons, leaving patients with memory, learning and motor deficits ${ }^{1,2)}$. The pathophysiology of cerebral ischemia is complex and involves numerous processes, including energy failure, ionic imbalances, acidosis, excitotoxicity, inflammatory pathways, increase of free radicals and disturbance of protein synthesis ${ }^{3)}$. Numerous neuroprotective agents that antagonize the injurious events have been identified in animal studies but most of them have failed to provide protection in clinical trials ${ }^{4}$. Recent studies have indicated that targeting a single pathway might be ineffective due to multiple pathologic processes, and thus combination therapies or neuroprotectants with pleiotropic effects have been

\footnotetext{
*Corresponding author : Hocheol Kim, Department of Herbal Pharmacology, College of Korean Medicine, Kyung Hee University, 26 Kyungheedaero, Dongdaemun-gu, Seoul 024447, Republic of Korea.

· Tel : +82-2-961-0419 · E-mail : hckim@khu.ac.kr

\#First author : Jungbin Song, Department of Herbal Pharmacology, College of Korean Medicine, Kyung Hee University, 26 Kyungheedaero, Dongdaemun-gu, Seoul 024447, Republic of Korea.

· Tel : +82-2-961-0419 · E-mail : jbsong@khu.ac.kr

- Received : 1 June 2016 - Revised : 14 June 2016 - Accepted : 18 July 2016
} 
suggested as an alternative ${ }^{4,5)}$. Medicinal plants which contain various compounds with different neuroprotective mechanisms could be a potentially rich source of neuroprotective agents.

HT070 is a mixture of herbal extracts from the root of Scutellaria baicalensis Georgi (Lamiaceae) and the stem bark of Eleutherococcus senticosus (Rupr. \& Maxim.) Maxim. (Araliaceae), which has been widely used in traditional Korean medicine. Scutellariae Radix has been reported to exert anti-inflammatory, anti-viral, anti-oxidant, anti-cancer, immunomodulating and anti-hyperlipidemic effects ${ }^{6)}$. The active components of Scutellariae Radix are flavonoids; the three major flavonoids are baicalin and its aglycone baicalein, and wogonin. Eleutherococci Senticosi Cortex, also called 'Siberian Ginseng', has been reported to possess anti-oxidant, anti-diabetic, anti-fatigue, immunomodulating and anti-cancer effects $^{7)}$. It is rich in eleutherosides, especially eleutheroside $\mathrm{B}$ and $\mathrm{E}$, compounds that are responsible for its diverse pharmacological activities ${ }^{8)}$.

Scutellariae Radix and Eleutherococci Senticosi Cortex have a long history of use in stroke prevention and therapy ${ }^{9)}$ and have been intensively studied as neuroprotective agents in a variety of experimental brain injury models ${ }^{7,8,10)}$. Previously, our group found that Scutellariae Radix and Eleutherococci Senticosi Cortex had protective effects against hippocampal cell death on global cerebral ischemia in rats ${ }^{11,12)}$. Baicalin, a major flavonoid in Scutellariae Radix, attenuates global cerebral ischemia/reperfusion injury in gerbils by increasing the activities of anti-oxidative enzymes, such as superoxide dismutase and glutathione peroxidase, and non-enzymatic scavenger glutathione in hippocampus ${ }^{13)}$. Baicalein, the most effective antioxidant among major flavonoids of Scutellariae Radix in in vitro neuroprotection assay ${ }^{14)}$, increases the activities of antioxidant enzymes in chronic cerebral hypoperfused rats $^{15,16)}$. Its anti-oxidative properties may render this compound to improve ATP synthesis, reduce mitochondrial ROS production, regulate expression of $\mathrm{Bcl}-2$ family proteins, and inhibit cytochrome c release against chronic cerebral hypoperfusion ${ }^{16)}$. The fruits of $E$. senticosus has been reported to induce the expression of $\mathrm{HO}-1$, a crucial enzymatic intermediate in antioxidant defense mechanisms through Nrf2 and p38-CREB pathways, and thereby reduces ROS production and neuroinflammation in hippocampal and microglial cells $^{17)}$. Polysaccharides of Eleutherococci Senticosi Cortex protect hippocampal neurons from oxidative stress by inducing the expression of OGG1, which plays important roles in redox regulation against oxidative stress ${ }^{18)}$. These previous findings led us to hypothesize that Scutellariae Radix and Eleutherococci Senticosi Cortex in combination may simultaneously act on different steps of pathways involved in cerebral ischemia and thus serve as a potent neuroprotective agent.

In the present study, we investigated the neuroprotective effects of HT070 in global cerebral ischemia using a four-vessel occlusion (4-VO) rat model. To gain further insight into the possible mechanisms of HT070, we used hydrogen peroxide $\left(\mathrm{H}_{2} \mathrm{O}_{2}\right)$-induced rat pheochromocytoma (PC12) cells as an in vitro model. Cytotoxicity and the mRNA expression of Bax, Bcl-2, iNOS and COX-2 were measured by MTT assay and quantitative RT-PCR, respectively.

\section{Materials and Methods}

\section{Plant materials}

The root of $S$. baicalensis and the stem bark of $E$. senticosus were purchased from Tulaoba Zhongyao Yinpian Co., Ltd. (Anhui, China). The origin of plant materials was Neimenggu, China. Scutellariae Radix and Eleutherococci Senticosi Cortex were authenticated by Professor Hocheol Kim of the Department of Herbal Pharmacology, Kyung Hee University, where voucher specimens were deposited.

\section{Sample preparation and HPLC analysis}

The root of $S$. baicalensis and the stem bark of $E$. senticosus were extracted separately with water for $2 \mathrm{~h}$ at $100{ }^{\circ} \mathrm{C}$ in a reflux apparatus for two times. The filtrate was concentrated under reduced pressure and then the concentrate was spray-dried to yield a powder. The powders of Scutellariae Radix and Eleutherococci Senticosi Cortex were mixed in a ratio of $1: 2(\mathrm{w} / \mathrm{w})$. Samples were stored at $-4{ }^{\circ} \mathrm{C}$ until use. The quantitative authentication of individual powders and their mixture HT070 was performed on a Waters 
instrument (Waters Corp., USA) equipped with a Waters 1525 binary pump, a Waters 2707 autosampler, and a Waters 2998 PDA detector. Separation was achieved on Sunfire ${ }^{\mathrm{TM}} \mathrm{C}^{18}$ column $(5 \mu \mathrm{m} ; 250 \times 4.6 \mathrm{~mm}$ i.d.; WatersCorp., USA) at $40{ }^{\circ} \mathrm{C}$. The mobile phase composition was $0.1 \%$ phosphoric acid (A) and acetonitrile (B) eluted for separation as following: 0-35 min, 5\%-37\%; 35-37 min, 37\%-65\%; 37-38 min, 65\%-5\%; 38-45 min, 5\%-5\% solvent B. The flow rate was $1.0 \mathrm{~mL} / \mathrm{min}$. The injection volume was $10 \mu \mathrm{L}$ and effluent was monitored at $205 \mathrm{~nm}$. Baicalin and Eleutheroside E were chosen as marker compounds for Scutellariae Radix and Eleutherococci Senticosi Cortex, respectively. The extracts were analyzed in triplicate.

\section{Animals}

Male Wistar rats weighing 170-190 g were obtained from Samtako Co. (Osan, Korea) and allowed access to water and food ad libitum. Rats were acclimatized and maintained under a constant temperature $\left(23 \pm 1{ }^{\circ} \mathrm{C}\right)$, humidity $(60 \pm 10 \%)$, and a $12 \mathrm{~h}$ light/dark cycle (light on 07:00-19:00 h). Animal treatment and maintenance were carried out in accordance with the Principle of Laboratory Animal Care (NIH Publication No. 85-23, revised 1985) and the Animal Care and Use Guidelines of Kyung Hee University.

\section{Induction of transient global cerebral ischemia and sample treatment}

Transient global cerebral ischemia was induced using the four-vessel occlusion (4-VO) model described by Pulsinelli and Brierly ${ }^{19)}$. Briefly, under anesthesia with $2 \%$ isoflurane in $70 \% \mathrm{~N}_{2} \mathrm{O} / 30 \% \mathrm{O}_{2}$, the vertebral arteries were electrocauterized and both common carotid arteries were isolated using a loop of thread. On the following day, both common carotid arteries were occluded with aneurysm clips to induce global cerebral ischemia. After $10 \mathrm{~min}$ of occlusion, the aneurysm clips were removed to allow reperfusion. Rats displaying loss of righting reflex and with bilateral pupil dilation were included in the study. Rats which developed seizure activity during or after ischemia were excluded from the study. Rectal temperature was maintained at $37 \pm 0.5{ }^{\circ} \mathrm{C}$ until $6 \mathrm{~h}$ after ischemia. Rats were randomly allocated to three groups: sham-operated, control (rats with 4-VO and vehicle treatment) and HT070 group (rats with 4-VO and HT070 treatment). HT070 was dissolved in normal saline and administered orally at a dosage of 200 $\mathrm{mg} / \mathrm{kg}$ twice at 0 and $90 \mathrm{~min}$ after reperfusion. Rats in the control or sham-operated group were administered normal saline in the same manner. The shamoperated group received the same surgical procedures except for the occlusion of common carotid arteries.

\section{Histology}

Seven days after global cerebral ischemia, rats were anesthetized and perfused transcardially with heparinized $0.5 \%$ sodium nitrite saline, followed by $4 \%$ paraformaldehyde. Brains were removed, fixed and cut into $30 \mu \mathrm{m}$ sections on a sliding microtome (Microm HM 440E, Walldorf, Germany) and the sections were stained with cresyl violet (CV). Neuronal density in hippocampal CA1 region was measured according to the method described in our previous study ${ }^{12)}$. Viable cells in the total of six frames $(1.0 \mathrm{~mm} \times 1.0 \mathrm{~mm})$ of the left and right CA1 regions of 3 coronal sections (approximately $3.3,3.5$, and $3.7 \mathrm{~mm}$ caudal to the bregma) were measured at a magnification of $\times 400$ for each rat. Neuronal density was expressed as the mean number of viable cells per one frame. Cell counting was performed by an investigator blinded to the experimental groups.

\section{Cell culture}

Rat pheochromocytoma cells (PC12) purchased from Korean cell line bank (Seoul, Korea) were maintained in Dulbecco's modified Eagle's medium (DMEM), supplemented with $10 \%$ fetal bovine serum, $100 \mathrm{U} / \mathrm{mL}$ penicillin, and $100 \mu \mathrm{g} / \mathrm{mL}$ streptomycin (all Gibco; Thermo Fisher Scientific, Inc., USA) in a humidified atmosphere of $95 \%$ air and $5 \% \quad \mathrm{CO}_{2}$ at $37^{\circ} \mathrm{C}$. All experiments were carried out $24 \mathrm{~h}$ after the cells were seeded.

\section{Analysis of cell viability}

PC12 cells were seeded at a density of $2 \times 10^{4}$ cells/well in 96-well plates and cell viability was measured using MTT assay. To investigate the cytotoxicity of HT070 on PC12 cells, the cells were incubated with $\mathrm{HT070}$ for $24 \mathrm{~h}$ at $37^{\circ} \mathrm{C}$. For the $\mathrm{H}_{2} \mathrm{O}_{2}$ 
injury model, cells were pre-incubated with HT070 for $1 \mathrm{~h}$ and then treated with $\mathrm{H}_{2} \mathrm{O}_{2}$ in the presence of HT070 for $6 \mathrm{~h}$ at $37^{\circ} \mathrm{C}$ (final $\mathrm{H}_{2} \mathrm{O}_{2}$ concentration: 100 $\mu \mathrm{M})$. At the indicated time after treatment, $100 \mu \mathrm{L}$ of MTT solution $(0.5 \mathrm{mg} / \mathrm{mL})$ was added to each well followed by incubation for $1 \mathrm{~h}$ at $37{ }^{\circ} \mathrm{C}$. MTT solution was removed and the formazan was dissolved in $100 \mu$ L of dimethyl sulfoxide (DMSO). The absorbance was measured at $570 \mathrm{~nm}$ and $630 \mathrm{~nm}$ using Epoch 2 Microplate Spectrophotometer (Biotek Instruments, Inc., USA). Cell viability was expressed as the percentage of control cells.

\section{RNA extraction and Quantitative RT-PCR}

PC12 cells were seeded in $60 \mathrm{~mm}$ dishes at a density of $2 \times 10^{5}$ cells/dish. After $24 \mathrm{~h}$, cells were pretreated with HT070 12.5 and $25 \mathrm{ug} / \mathrm{mL}$ for $1 \mathrm{~h}$ and then exposed to $100 \mu \mathrm{M} \mathrm{H}_{2} \mathrm{O}_{2}$ for $6 \mathrm{~h}$ in the presence of HT070. Total cellular RNA was isolated from PC12 cells using QIAzol lysis reagent (Qiagen, USA). The concentration of total RNA was assessed using the Take $3^{\mathrm{TM}}$ Multi-volume Plate (BioTek, USA) and cDNA was synthesized using High-Capacity cDNA Reverse Transcription Kits (Applied Biosystems, USA). After cDNA synthesis, quantitative RT-PCR was performed in ABI 7500 Real Time PCR system (Applied Biosystems, USA) with Power SYBR Green PCR Master Mix (Applied Biosystems, USA). Relative gene expression was determined using the comparative $\mathrm{Ct}$ method and normalized to housekeeping gene GAPDH. The sequences of the primers are shown in Table 1.

Table 1. Sequences of the primers used in the quantitative RT-PCR

\begin{tabular}{ccc}
\hline Gene & Forward primer $\left(5^{\prime}-3^{\prime}\right)$ & Reverse primer $\left(5^{\prime}-3^{\prime}\right)$ \\
\hline \hline Bax & TGTTTGCTGATGGCAACTTC & GATCAGCTCGGGCACTTTAG \\
\hline Bcl-2 & GGGATGCCTTTGTGGAACTA & CTCACTTGTGGCCCAGGTAT \\
\hline iNOS & AGCGGCCCATGACTCTCA & CTGCACCCAAACACCAAGGT \\
\hline COX-2 & CCGTGGTGAATGTATGAGCA & GATTGACAGCCCACCACTT \\
\hline GAPDH & TGGCCTCCAAGGAGTAAGAAAC & CAGCAACTGAGGGCCTCTCT \\
\hline
\end{tabular}

\section{Statistical analysis}

All data were expressed as mean $\pm \mathrm{SD}$. One-way ANOVA followed by Tukey's test was used to compare the differences between multiple groups, and Student's t-test was used for two groups. Statistical significance was set at $P<0.05$.

\section{Results}

\section{HPLC Analysis}

Three dimensional HPLC chromatograms and the structures of the constituent compounds are shown in Figure 1. HPLC analysis showed that extract of Scutellariae Radix contained $170.80 \mathrm{mg} / \mathrm{g}$ of baicalin, extract of Eleutherococci Senticosi Cortex contained $8.94 \mathrm{mg} / \mathrm{g}$ of eleutheroside $\mathrm{E}$, and their mixture HT070 contained $63.36 \mathrm{mg} / \mathrm{g}$ of baicalin and 6.10 $\mathrm{mg} / \mathrm{g}$ of eleutheroside $\mathrm{E}$.

A

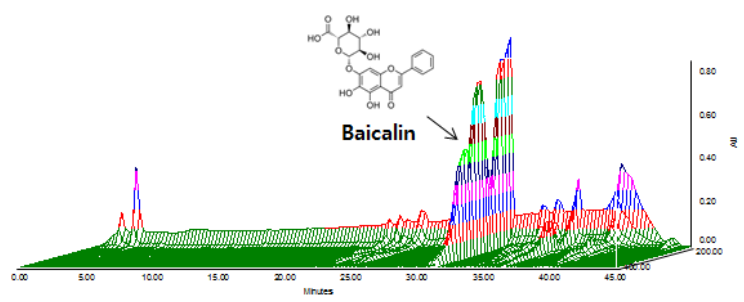

B

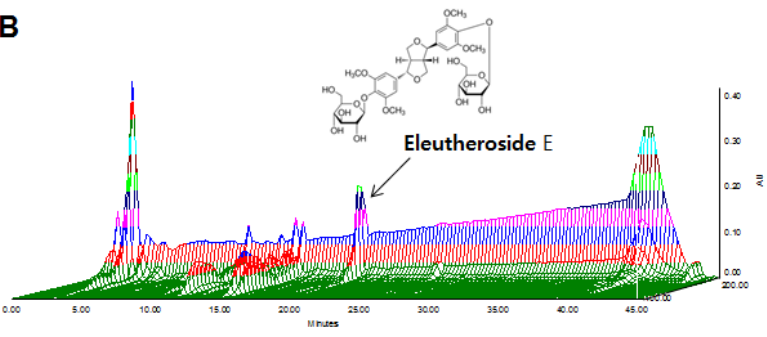

C

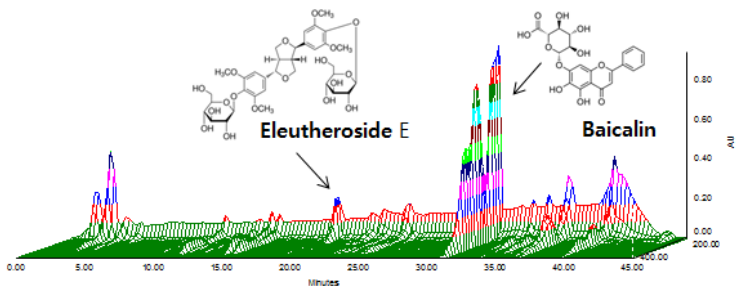

Figure 1. Three dimensional HPLC chromatograms of Scutellariae Radix extract (A), Eleutherococci Senticosi Cortex extract (B) and HTO7O (C). X-axis is retention time; $Y$-axis is wavelength, and $Z$-axis is absorbance unit.

\section{Effects of HT070 on neuronal density in} rat hippocampal CA1 region

A typical feature of $4-\mathrm{VO}$ rat model is delayed and selective loss of pyramidal neurons in hippocampal CA1. As expected, the number of viable neurons sharply decreased in the hippocampal CA1 region at 7 days following reperfusion. Under magnification, sham- 
operated rats showed viable neurons with round nuclei and intact morphology, whereas control rats displayed neurons with shrunken cell bodies and pyknotic nuclei (Figure 2D vs. E). To quantify the extent of the neuronal damage, we counted the number of surviving pyramidal neurons in the hippocampal CA1 subfield (Figure 3). A marked reduction in neuronal density was observed in the control group $\left(67.2 \pm 12.3\right.$ cells $\left./ \mathrm{mm}^{2}\right)$ in comparison to the sham-operated group. In contrast, oral administration of HT070 at a dose of $200 \mathrm{mg} / \mathrm{kg}$

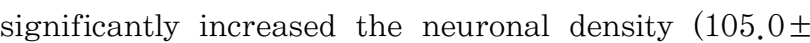
33.1 cells $/ \mathrm{mm}^{2}, 13.4 \%$, p <0.05) compared to control group.

Sham
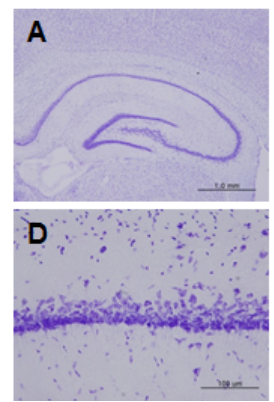

Figure 2. Representative photomicrographs of cresyl violetstained hippocampus of sham-operated (A, D), control (B, E), and HTO70-treated rats (C, F). Transient global cerebral ischemia resulted in delayed neuronal cell death in the hippocampal CA1 region (B, E). HT070 $200 \mathrm{mg} / \mathrm{kg}$-treated group showed a reduction of the number of irreversibly damaged pyramidal cells in the CA1 subfield (C, F). Scale bars: $1 \mathrm{~mm}$ in A-C; $100 \mu \mathrm{m}$ in $D-F$.

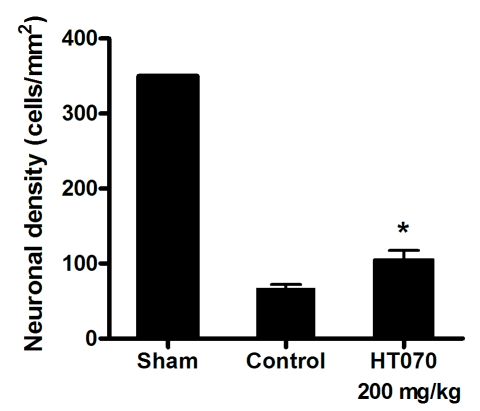

Figure 3. Neuroprotective effects of HTO70 in a rat model of global cerebral ischemia. Either a vehicle or HT070 $200 \mathrm{mg} / \mathrm{kg}$ was orally administered at 0 and $90 \mathrm{~min}$ after reperfusion. Seven days after reperfusion, neuronal density in CA1 region was measured by counting viable cells. Treatment with HTO70 significantly protected CA1 neurons from global cerebral ischemia $(p<0.05)$. The values are mean $\pm S D .{ }^{*} p<0.05$ vs. control group. Sham, sham-operated group $(n=1)$; Control, $4-\mathrm{VO}$ rats treated with vehicle $(n=6)$; HTO70 $200 \mathrm{mg} / \mathrm{kg}, 4-\mathrm{VO}$ rats treated with HTO70 $200 \mathrm{mg} / \mathrm{kg}(\mathrm{n}=7)$.

\section{Effects of HT070 on PC12 cell viability}

To establish the non-cytotoxic concentration range, PC12 cells were treated with different concentrations of HT070 for $24 \mathrm{~h}$. As shown in Figure 4A, in the range of concentration $12.5-100 \mu \mathrm{g} / \mathrm{mL}$, HT070 did not affect cell viability as compared to control cells. The protective effects of HT070 against oxidative stress-induced neuronal injury were assessed in $\mathrm{H}_{2} \mathrm{O}_{2}$-treated PC12 cells. The results shown in Figure $4 \mathrm{~B}$ suggest that exposure to $\mathrm{H}_{2} \mathrm{O}_{2}$ at $100 \mu \mathrm{M}$ for $6 \mathrm{~h}$ caused significant cytotoxicity compared to control cells. Treatment with HT070 over the range of concentrations from 12.5 to $100 \mu \mathrm{g} / \mathrm{mL}$ significantly increased the percentage of viable cells as compared to cells treated with only $\mathrm{H}_{2} \mathrm{O}_{2}$. Since a concentration of $25 \mu \mathrm{g} / \mathrm{mL}$ was more effective than a higher concentration (50-100 $\mu \mathrm{g} / \mathrm{mL}$ ), it was decided to use the concentrations of 12.5 and $25 \mu \mathrm{g} / \mathrm{mL}$ for further mechanism studies.

A

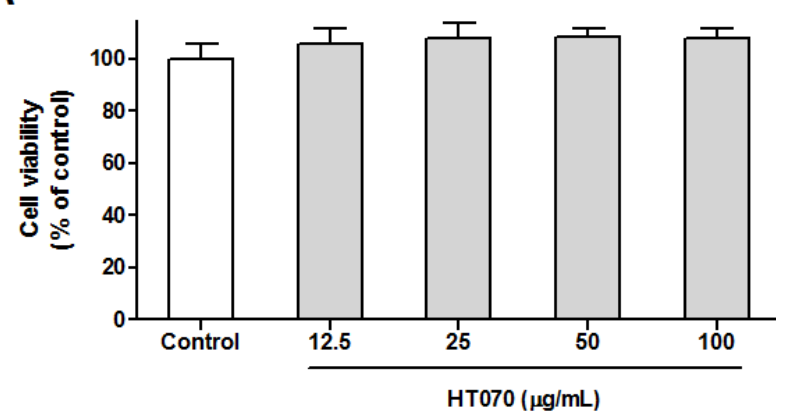

B

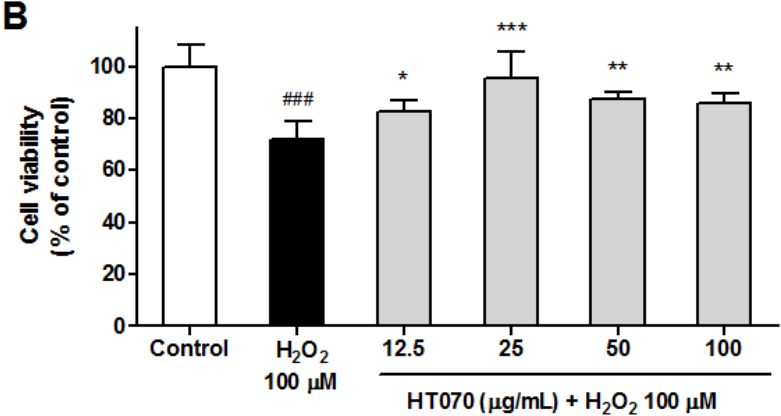

Figure 4. Effect of $\mathrm{HTO} 0$ on $\mathrm{H}_{2} \mathrm{O}_{2}$-induced cytotoxicity in $\mathrm{PC} 12$ cells. (A) PC12 cells were treated with HT070 for $24 \mathrm{~h}$. (B) PC12 cells were treated with $100 \mu \mathrm{M} \mathrm{H}_{2} \mathrm{O}_{2}$ for $6 \mathrm{~h}$ after pretreatment with $\mathrm{HTO} 0 \mathrm{O}$ for $1 \mathrm{~h}$. Cell viability was measured using MTT assay and were expressed as a percentage of the control. Values are given as the mean $\pm S D$. \#\#\#p<0.001 vs. control group. ${ }^{*} p$ $\left\langle 0.05,{ }^{* *} \mathrm{p}\left\langle 0.01,{ }^{* * *} \mathrm{p}\left\langle 0.001\right.\right.\right.$ vs. $\mathrm{H}_{2} \mathrm{O}_{2}$ only-treated group.

\section{Effect of HT070 on the mRNA levels of} Bax and Bcl-2 in $\mathrm{H}_{2} \mathrm{O}_{2}$-induced PC12 cells

As shown in Figure 5, after treatment with $100 \mu \mathrm{M}$ $\mathrm{H}_{2} \mathrm{O}_{2}$ for $6 \mathrm{~h}$, quantitative RT-PCR analysis showed that mRNA levels of Bax increased (1.6-fold), while those of Bcl-2 decreased (0.2-fold). HT070 at the 
concentrations of 12.5 and $25 \mu \mathrm{g} / \mathrm{mL}$ significantly reduced Bax and raised $\mathrm{Bcl}-2$ expressions in $\mathrm{PC1} 2$ cells treated with $\mathrm{H}_{2} \mathrm{O}_{2}$.

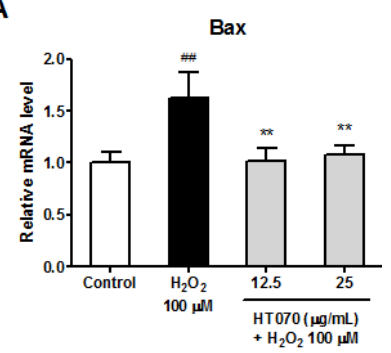

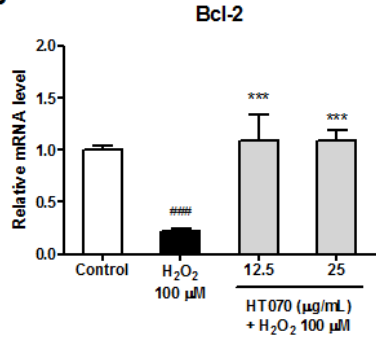

Figure 5. Effect of HTO70 on the mRNA levels of Bax and $\mathrm{Bcl}-2$ in $\mathrm{H}_{2} \mathrm{O}_{2}$-induced $\mathrm{PC} 12$ cells. PC12 cells were pretreated with HT070 12.5 and $25 \mathrm{ug} / \mathrm{mL}$ for $1 \mathrm{~h}$ and then exposed to $100 \mu$ $\mathrm{M} \mathrm{H}_{2} \mathrm{O}_{2}$ for $6 \mathrm{~h}$. The mRNA expressions of $\mathrm{Bax}(\mathrm{A})$ and $\mathrm{Bcl}-2$ (B) were measured by quantitative RT-PCR and normalized to GAPDH mRNA. Results are expressed as mean \pm SD. \#\#p $\langle 0.01$, \#\#p <0.001 vs. control group. ${ }^{* *} p\left\langle 0.01,{ }^{* * *} p<0.001\right.$ vs. $\mathrm{H}_{2} \mathrm{O}_{2}$ only-treated group.

\section{Effect of HT070 on the mRNA levels of iNOS and $\mathrm{COX}-2$ in $\mathrm{H}_{2} \mathrm{O}_{2}$-induced $\mathrm{PC} 12$} cells.

The effects of HT070 on $\mathrm{H}_{2} \mathrm{O}_{2}$-induced upregulation of iNOS and COX-2 mRNA were measured by quantitative RT-PCR. As shown in Figure 6, increases in iNOS and COX-2 mRNA expressions were observed when cells were treated with $100 \mu \mathrm{M} \mathrm{H}_{2} \mathrm{O}_{2}$ for $6 \mathrm{~h}$ (5.3 and 8.0-folds). HT070 at the concentrations of 12.5 and $25 \mu \mathrm{g} / \mathrm{mL}$ markedly inhibited $\mathrm{H}_{2} \mathrm{O}_{2}-$ induced increase in iNOS and COX-2 mRNA expressions compared to $\mathrm{H}_{2} \mathrm{O}_{2}$-treated cells. Especially, COX-2 mRNA levels in HT070-treated cells were similar to that in control (normal) cells.
A

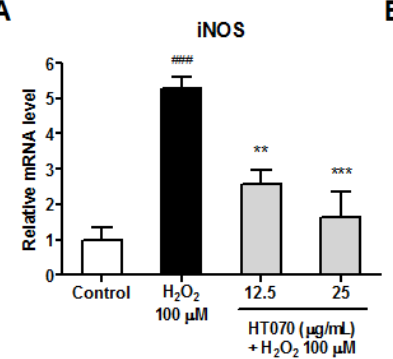

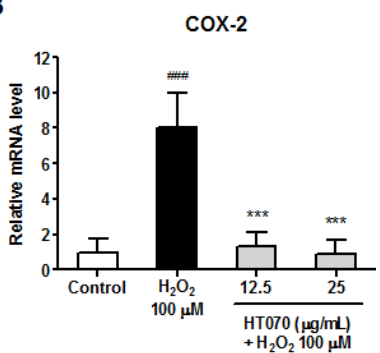

Figure 6. Effect of HTO70 on the mRNA levels of iNOS and COX-2 in $\mathrm{H}_{2} \mathrm{O}_{2}$-induced $\mathrm{PC} 12$ cells. PC12 cells were pretreated with HT070 12.5 and $25 \mathrm{ug} / \mathrm{mL}$ for $1 \mathrm{~h}$ and then exposed to $100 \mu \mathrm{M} \mathrm{H}_{2} \mathrm{O}_{2}$ for $6 \mathrm{~h}$. The mRNA expressions of iNOS (A) and COX-2 (B) were measured by quantitative RT-PCR, which were normalized to GAPDH mRNA. Results are expressed as mean $\pm S D$. \#\#\#p $\left\langle 0.001\right.$ vs. control group. ${ }^{* *} p$ $\left\langle 0.01,{ }^{* * *} \mathrm{p}\left\langle 0.001\right.\right.$ vs. $\mathrm{H}_{2} \mathrm{O}_{2}$ only-treated group.

\section{Discussion}

Findings from in vivo studies showed that oral administration of $\mathrm{HTO} 70$ at a dose of $200 \mathrm{mg} / \mathrm{kg}$ significantly attenuated neuronal cell death in the hippocampal CA1 region after transient global cerebral ischemia induced by $4-\mathrm{VO}$. Our in vitro studies showed that HT070 exerted protective effects against $\mathrm{H}_{2} \mathrm{O}_{2}$-induced cytotoxicity and restored the downregulated Bcl-2 mRNA level and up-regulated Bax, iNOS, and COX-2 mRNA expression in PC12 cells.

A brief period of global cerebral ischemia causes selective neuronal death in vulnerable brain areas, including the hippocampal CA1 region. Hippocampal neuronal death usually occurs at day 3 or 4 and peaks at 7 days after an initial ischemic insult, the so-called delayed neuronal death ${ }^{20)}$. The four-vessel occlusion (4-VO) model used in this study is a well-established and widely used technique for induction of global cerebral ischemia ${ }^{19)}$. In the present study, 4-VO rats showed a significant decrease in neuronal densities in the CA1 region compared to sham-operated group at 7 days after reperfusion. Oral administration of HT070 at a dose of $200 \mathrm{mg} / \mathrm{kg}$ at 0 and $90 \mathrm{~min}$ after reperfusion significantly increased neuronal density in the hippocampal CA1 region, suggesting that HT070 has neuroprotective effects against delayed neuronal death induced by global cerebral ischemia. Considering the potential of using HT070 as a dietary ingredient in dairy products, we additionally tested the effects of HT070-added milk in 4-VO model. HT070-added milk sterilized by ultra-high temperature processing $\left(132{ }^{\circ} \mathrm{C}\right.$ for $3 \mathrm{sec}$ ) also provided significant neuroprotection against delayed neuronal damage (data not shown).

To investigate the mechanisms underlying the neuroprotective effects of $\mathrm{HT} 070, \mathrm{H}_{2} \mathrm{O}_{2}$ was used to develop an oxidative stress in $\mathrm{PC} 12$ cells. Oxidative stress has been implicated as a major cause of cellular injuries in cerebral ischemia. Accumulating evidences suggest that delayed neuronal cell death induced by global cerebral ischemia/reperfusion is directly or indirectly linked to oxidative stress, which is mediated by reactive oxygen species ${ }^{21)}$. During ischemiareperfusion, superoxide anions $\left(\mathrm{O}_{2}{ }^{--}\right)$are produced in the brain and further detoxified to $\mathrm{H}_{2} \mathrm{O}_{2}$ by superoxide dismutase (SOD). Hydroxyl radicals $(\bullet \mathrm{OH})$ are then produced from $\mathrm{H}_{2} \mathrm{O}_{2}$ through the Fenton and HaberWeiss reactions or by peroxynitrite, and they irreversibly oxidize macromolecules including DNA, lipid and 
protein, and eventually cause severe cell injury. Thus, $\mathrm{H}_{2} \mathrm{O}_{2}$ has been used extensively as an inducer of oxidative stress in in vitro neuroprotection assay. The PC12 cells, derived from a rat adrenal medullary pheochromocytoma, provide an established neuronlike system ${ }^{22)}$, and thereby are commonly used as a model for investigating neuroprotection against oxidative stress. In the present study, treatment with HT070 at concentrations $\geq 12.5 \mu \mathrm{g} / \mathrm{mL}$ significantly reduced $\mathrm{H}_{2} \mathrm{O}_{2}$-induced cytotoxicity in PC12 cells, suggesting neuroprotection against oxidative stress.

After confirming the protective effects of HT070 on $\mathrm{H}_{2} \mathrm{O}_{2}$-induced cytotoxicity, we focused on the mitochondria-dependent apoptotic pathway. The mitochondria-dependent apoptotic pathway is known to be involved in $\mathrm{H}_{2} \mathrm{O}_{2}$-induced cytotoxicity in $\mathrm{PC} 12$ cells, and the Bcl-2 family plays pivotal roles in this pathway $^{23)}$. Bcl-2 family proteins, mainly located on the mitochondrial membrane, regulate cell survival and apoptosis, which may be either anti-apoptotic (e.g. Bcl-2 and Bcl-XL) or pro-apoptotic (e.g. Bax, Bak, $\mathrm{Bid}$, Bad and Bik) ${ }^{24)}$. Lowered Bcl-2 and increased Bax expression, both of which have been demonstrated as early events in the process of apoptosis, alter mitochondrial membrane permeability, induce the release of cytochrome $c$ or trigger caspase cascade activation in neurons ${ }^{25)}$. In accordance with a previous study ${ }^{26)}$, our current study showed a remarkable decrease of Bcl-2 and increase of the Bax mRNA levels in PC12 cells following $\mathrm{H}_{2} \mathrm{O}_{2}$ exposure. HT070 significantly attenuated $\mathrm{H}_{2} \mathrm{O}_{2}$-induced upregulation of $\mathrm{Bax}$ and rehabilitated the Bcl-2 level at the $6 \mathrm{~h}$ time point. These results suggest that the modulation of apoptosis-related gene expression might at least partly contribute to the protective effect of HT070 against neuronal injury. Baicalin and baicalein, the major active flavonoids in Scutellariae Radix, have been reported to modulate the expression of Bcl-2 family proteins and block the caspase cascade in $\mathrm{H}_{2} \mathrm{O}_{2}$-induced $\mathrm{PC} 12$ cells ${ }^{27,28)}$. These studies support our suggestion and indicate that flavonoids in HT070 are responsible for the modulation of apoptosis-related gene expression.

iNOS and COX -2 are known to play pivotal roles in the generation of free radicals in ischemic stroke ${ }^{29)}$ and free radicals themselves can increase and/or induce the expression of iNOS and COX-2 $2^{30-32)}$. Increased iNOS after cerebral ischemia serves as the major source of nitric oxide (NO) production and NO reacts with most free radicals with one unpaired electron ${ }^{33)}$. Reaction of NO with superoxide anion leads to the production of peroxynitrite $\left(\mathrm{ONOO}^{-}\right)$, a highly reactive oxidant with neurotoxic actions ${ }^{34)}$. COX-2, possessing two active sites, catalyzes two key steps in the conversion of arachidonic acid (AA) to prostaglandin $\mathrm{H}_{2}\left(\mathrm{PGH}_{2}\right)$. The first active site utilizes two oxygen molecules to form the hydroxy endoperoxide prostaglandin $\mathrm{G}_{2}\left(\mathrm{PGG}_{2}\right)$ from $\mathrm{AA}$. Subsequently, $\mathrm{PGG}_{2}$ is converted to $\mathrm{PGH}_{2}$ by peroxidative reduction in the second active site. This peroxidase activity of COX reduces $\mathrm{PGG}_{2}$ to $\mathrm{PGH}_{2}$ by removal of oxygen, which may be a source of oxygen radicals ${ }^{35,36)}$. It has been demonstrated in PC12 cells that iNOS and COX-2 mRNA levels are increased subsequent to $\mathrm{H}_{2} \mathrm{O}_{2}$ treatment ${ }^{37-39)}$ and iNOS-specific inhibitor blocks $\mathrm{H}_{2} \mathrm{O}_{2}-$ mediated apoptosis in PC12 cells ${ }^{40)}$. In addition, it has been demonstrated that COX-dependent neuronal death proceeds via superoxide anion generation ${ }^{41)}$. Results of the present study showed that $\mathrm{H}_{2} \mathrm{O}_{2}$ increased the expression of $\mathrm{iNOS}$ and $\mathrm{COX}-2$, a finding in agreement with previous studies, and that pretreatment with HT047 inhibited this effect. These results suggest that the modulation of enzyme expression responsible for secondary generation of ROS may be related to the protective effect of HT070 against oxidative stressinduced neuronal injury.

Our in vitro data suggest that the neuroprotective effect of HT070 against global cerebral ischemia might be partly associated with inhibition of oxidative stress by modulation of Bax and Bcl-2 expression and blocking iNOS and COX-2 expression. Findings from previous studies support our suggestion: Baicalin, the major active compounds in Scutellariae Radix, attenuates neuronal apoptosis in global cerebral ischemia by inhibition of the caspase-3, known to act downstream of $\mathrm{Bax} / \mathrm{Bcl}-2$, and by reduction of $\mathrm{COX}-2$ expression in the hippocampal CA1 region ${ }^{13,42)}$. E. seticosus protects delayed neuronal death and reduces COX-2 expression in the CA1 region of the hippocampus after global cerebral ischemia in rats $^{12)}$.

\section{Conclusion}

This study addressed the neuroprotective effects of HT070 after global cerebral ischemia and the possible mechanisms underlying neuroprotection. The summary 
of results and conclusion are as follows:

1. Oral administration of HT070 significantly increased neuronal density in rat hippocampal CA1 region following four-vessel occlusion.

2. HT070 exerted protective effects against $\mathrm{H}_{2} \mathrm{O}_{2}-$ induced cytotoxicity in PC12 cells.

3. HT070 restored the down-regulated Bcl-2 mRNA level and up-regulated Bax, iNOS, and COX-2 mRNA expression in $\mathrm{H}_{2} \mathrm{O}_{2}$-treated $\mathrm{PC} 12$ cells.

Taken together, HT070 protects against against delayed neuronal death after global cerebral ischemia and its neuroprotective effects might be achieved at least in part by the inhibition of mitochondrial apoptosis and reduction of the expression of ROS-generating enzymes. With a long history of human use, HT070 has potential for neuroprotection in global cerebral ischemia.

\section{Acknowledgement}

This study was supported by a grant of the Seoul Dairy Cooperative R\&D Center, Republic of Korea.

\section{References}

1. Zola-Morgan S, Squire LR, Amaral DG. Human amnesia and the medial temporal region: enduring memory impairment following a bilateral lesion limited to field CA1 of the hippocampus. J Neurosci. $1986 ; 6(10): 2950-67$.

2. Lim C, Alexander MP, LaFleche G, Schnyer DM, Verfaellie M. The neurological and cognitive sequelae of cardiac arrest. Neurology. 2004 ; 63(10) : 1774-8.

3. Woodruff TM, Thundyil J, Tang SC, Sobey CG, Taylor SM, Arumugam TV. Pathophysiology, treatment, and animal and cellular models of human ischemic stroke. Mol Neurodegener. 2011 ; 6(1) : 11.

4. Majid A. Neuroprotection in stroke: past, present, and future. ISRN Neurol. $2014 ; 2014$ : 515716.

5. Onwuekwe I, Ezeala-Adikaibe B. Ischemic stroke and neuroprotection. Ann Med Health Sci Res. 2012 ; 2(2) : 186-90.

6. Li C, Lin G, Zuo Z. Pharmacological effects and pharmacokinetics properties of Radix Scutellariae and its bioactive flavones. Biopharm Drug Dispos. $2011 ; 32(8): 427-45$
7. Sun Y, Liu L, Hong S. Eleutherococcus senticosus as a crude medicine: Review of biological and pharmacological effects. J. Med. Plants Res. 2011 ; 5(25) : 5946-52.

8. Huang L, Zhao H, Huang B, Zheng C, Peng W, Qin L. Acanthopanax senticosus: review of botany, chemistry and pharmacology. Pharmazie. 2011 ; $66(2): 83-97$.

9. Kim H. Neuroprotective herbs for stroke therapy in traditional eastern medicine. Neurol Res. 2005 ; 27(3) : 287-301.

10. Gaire BP, Moon SK, Kim H. Scutellaria baicalensis in stroke management: nature's blessing in traditional Eastern medicine. Chin J Integr Med. $2014 ; 20(9): 712-20$.

11. Kim YO, Leem K, Park J, Lee P, Ahn DK, Lee BC, Park HK, Suk K, Kim SY, Kim H. Cytoprotective effect of Scutellaria baicalensis in CA1 hippocampal neurons of rats after global cerebral ischemia. $J$ Ethnopharmacol. $2001 ; 77(2-3)$ : 183-8.

12. Lee D, Park J, Yoon J, Kim MY, Choi HY, Kim H. Neuroprotective effects of Eleutherococcus senticosus bark on transient global cerebral ischemia in rats. J Ethnopharmacol. 2012 ; 139(1) : 6-11.

13. Cao Y, Mao X, Sun C, Zheng P, Gao J, Wang X, Min D, Sun H, Xie N, Cai J. Baicalin attenuates global cerebral ischemia/reperfusion injury in gerbils via anti-oxidative and anti-apoptotic pathways. Brain Res Bull. 2011 ; 85(6) : 396-402.

14. Gao Z, Huang K, Yang X, Xu H. Free radical scavenging and antioxidant activities of flavonoids extracted from the radix of Scutellaria baicalensis Georgi. Biochim Biophys Acta. 1999 ; 1472(3) : $643-50$

15. Liu C, Wu J, Gu J, Xiong Z, Wang F, Wang J, Wang W, Chen J. Baicalein improves cognitive deficits induced by chronic cerebral hypoperfusion in rats. Pharmacol Biochem Behav. 2007 ; 86(3) : $423-30$

16. He XL, Wang YH, Gao M, Li XX, Zhang TT, Du GH. Baicalein protects rat brain mitochondria against chronic cerebral hypoperfusion-induced oxidative damage. Brain Res. 2009 ; 1249 : 212-21.

17. Jin ML, Park SY, Kim YH, Park G, Lee SJ. Acanthopanax senticosus exerts neuroprotective effects through $\mathrm{HO}-1$ signaling in hippocampal and microglial cells. Environ Toxicol Pharmacol. $2013 ; 35(2): 335-46$.

18. Diao B, Tang Y, Yang L, Wen Y. Effects of acanthopanacis senticosi polysaccharides on expression of OGG1 mRNA in hippocampal 
neurons damaged by oxidative stress. Chin J Gerontol. 2009 ; 29 : 396-9.

19. Pulsinelli WA, Brierley JB. A new model of bilateral hemispheric ischemia in the unanesthetized rat Stroke. $1979 ; 10(3): 267-72$.

20. Kirino T. Delayed neuronal death in the gerbil hippocampus following ischemia. Brain Res. 1982 ; 239(1) : 57-69.

21. Kawase M, Murakami K, Fujimura M, MoritaFujimura Y, Gasche Y, Kondo T, Scott RW, Chan $\mathrm{PH}$. Exacerbation of delayed cell injury after transient global ischemia in mutant mice with CuZn superoxide dismutase deficiency. Stroke. 1999 ; 30(9) : 1962-8.

22. Gunning PW, Landreth GE, Layer P, Ignatius M, Shooter EM. Nerve growth factor-induced differentiation of PC12 cells: evaluation of changes in RNA and DNA metabolism. J Neurosci. 1981 ; 1(4) : 368-79.

23. Czabotar PE, Lessene G, Strasser A, Adams JM. Control of apoptosis by the BCL-2 protein family: implications for physiology and therapy. Nat Rev Mol Cell Biol. 2014 ; 15(1) : 49-63.

24. Tait SW, Green DR. Mitochondria and cell death: outer membrane permeabilization and beyond. Nat Rev Mol Cell Biol. 2010 ; 11(9) : 621-32.

25. Soane L, Fiskum G. Inhibition of mitochondrial neural cell death pathways by protein transduction of Bcl-2 family proteins. $J$ Bioenerg Biomembr. $2005 ; 37(3): 179-90$.

26. Wu FJ, Xue Y, Liu XF, Xue CH, Wang JF, Du L, Takahashi K, Wang YM. The protective effect of eicosapentaenoic acid-enriched phospholipids from sea cucumber Cucumaria frondosa on oxidative stress in PC12 cells and SAMP8 mice. Neurochem Int. $2014 ; 64: 9-17$.

27. Zhang S, Ye J, Dong G. Neuroprotective effect of baicalein on hydrogen peroxide-mediated oxidative stress and mitochondrial dysfunction in PC12 cells. J Mol Neurosci. 2010 ; 40(3) : 311-20.

28. Zheng WX, Wang F, Cao XL, Pan HY, Liu XY, Hu $\mathrm{XM}$, Sun YY. Baicalin protects $\mathrm{PC}-12$ cells from oxidative stress induced by hydrogen peroxide via anti-apoptotic effects. Brain Inj. 2014 ; 28(2) : 227-34.

29. Pradeep H, Diya JB, Shashikumar S, Rajanikant GK. Oxidative stress-assassin behind the ischemic stroke. Folia Neuropathol. 2012 ; 50(3) : 219-30.

30. Nakamura T, Sakamoto K. Reactive oxygen species up-regulates cyclooxygenase-2, p53, and Bax mRNA expression in bovine luteal cells. Biochem Biophys Res Commun. 2001；284(1) : 203-10.
31. Adderley SR, Fitzgerald DJ. Oxidative damage of cardiomyocytes is limited by extracellular regulated kinases 1/2-mediated induction of cyclooxygenase-2. J Biol Chem. 1999 ; 274(8) : 5038-46.

32. Feng L, Xia Y, Garcia GE, Hwang D, Wilson CB. Involvement of reactive oxygen intermediates in cyclooxygenase-2 expression induced by interleukin -1 , tumor necrosis factor $-\alpha$, and lipopolysaccharide. J Clin Invest. 1995 ; 95(4) : 1669-75.

33. Nomura Y. Neuronal apoptosis and protection: effects of nitric oxide and endoplasmic reticulumrelated proteins. Biol Pharm Bull. 2004 ; 27(7) : 961-3.

34. Jhaveri KA, Toth LA, Sekino Y, Ramkumar V. Nitric oxide serves as an endogenous regulator of neuronal adenosine A1 receptor expression. J Neurochem. 2006 ; 99(1) : 42-53.

35. Smith WL, Garavito RM, DeWitt DL. Prostaglandin endoperoxide $\mathrm{H}$ synthases (cyclooxygenases)-1 and -2. J Biol Chem. 1996 ; 271(52) : 33157-60.

36. Kukreja RC, Kontos HA, Hess ML, Ellis EF. PGH synthase and lipoxygenase generate superoxide in the presence of NADH or NADPH. Circ Res. 1986 ; 59(6) : 612-9.

37. Kuang R, Sun Y, Zheng X, Ni W, Zhu S. Lipoic acid protected PC12 cells from oxidative stressinduced damage by inhibiting the $\mathrm{NF}-\kappa \mathrm{B}-\mathrm{iNOS}-\mathrm{NO}$ signal pathway. Chin JMAP. 2009 ; 26(7) : 538-41.

38. Xu HB, Li L, Liu GQ. Protection against hydrogen peroxide-induced cytotoxicity in PC12 cells by guggulsterone. Yao Xue Xue Bao. 2008 ; 43(12) : 1190-7.

39. Yu SL, Lin SB, Yu YL, Chien MH, Su KJ, Lin CJ, Way TD, Yiang GT, Lin CC, Chan DC, Harn HJ, Chen YL. Isochaihulactone protects PC12 cell against $\mathrm{H} 2 \mathrm{O} 2$ induced oxidative stress and exerts the potent anti-aging effects in D-galactose aging mouse model. Acta Pharmacol Sin. 2010 ; 31(12) : $1532-40$.

40. Lee MK, Lu Y, Di LQ, Xu HQ. Protection of Tong-Sai-Mai Decoction against Apoptosis Induced by $\mathrm{H} 2 \mathrm{O} 2$ in PC12 Cells: Mechanisms via Bcl-2Mitochondria-ROS-INOS Pathway. Evid Based Complement Alternat Med. 2014 ; 2014 : 371419.

41. Im JY, Kim D, Paik SG, Han PL. Cyclooxygenase2-dependent neuronal death proceeds via superoxide anion generation. Free Radic Biol Med. 2006 ; 41(6) : 960-72.

42. Cheng O, Li Z, Han Y, Jiang Q, Yan Y, Cheng K. Baicalin improved the spatial learning ability of global ischemia/reperfusion rats by reducing hippocampal apoptosis. Brain Res. 2012 ; 1470 : 111-8. 